\title{
Pengaruh Penilaian Kinerja dan Kecerdasan Emosional Berdasarkan Project Based Learning (PjBL) terhadap Hasil Belajar Matematika Siswa
}

\author{
Nanly Ollyvia Putri Hestu Biantoro ${ }^{1 *}$, Febriana Kristanti ${ }^{2}$, Himmatul Mursyidah $^{3}$ \\ 1,2,3 Universitas Muhammadiyah Surabaya \\ *nanlyollyviaputrihestubiantoro@gmail.com
}

\begin{abstract}
ABSTRAK
Penelitian ini bertujuan untuk mengetahui pengaruh penilaian kinerja siswa dan kecerdasan emosional siswa selama proses pembelajaran berdasarkan PjBL terhadap hasil belajar siswa. Penelitian ini menggunakan metode kuantitatif dengan desain penelitian korelasi. Sampel penelitian berada pada kelas VII-B SMP Muhammadiyah 10 Surabaya yang berjumlah 19 siswa. Instrumen yang digunakan yaitu soal tes materi perbandingan, lembar observasi kinerja siswa, dan angket kecerdasan emosional. Hasil penelitian menunjukan bahwa: (1) berdasarkan uji regresi linear sederhana variabel penilaian kinerja terhadap hasil belajar, diperoleh $F_{\text {hitung }}>F_{\text {tabel }}$ yaitu $4,632>4,45$, artinya terdapat pengaruh penilaian kinerja terhadap hasil belajar sebesar $42,5 \%$; (2) berdasarkan uji regresi linear sederhana variabel kecerdasan emosional terhadap hasil belajar, diperoleh $F_{\text {hitung }}>F_{\text {tabel }}$ yaitu 5,733 $>4,45$, artinya terdapat pengaruh kecerdasan emosional terhadap hasil belajar sebesar 33,6\%;(3) berdasarkan uji regresi linear berganda variabel penilaian kinerja dan kecerdasan emosional terhadap hasil belajar, diperoleh $F_{\text {hitung }}>F_{\text {tabel }}$ yaitu 3,672 $>$ 3,59 , artinya terdapat pengaruh penilaian kinerja dan kecerdasan emosional terhadap hasil belajar sebesar $60,7 \%$.
\end{abstract}

Kata kunci: kecerdasan emosional, penilaian kinerja, Project Based Learning (PjBL).

\section{ABSTRACT}

This study aims to determine the effect of student performance assessment and student emotional intelligence during the learning process based on Project Based Learning (PjBL) on student learning outcomes. This research used quantitative method within a research design correlation. The number of sample of this study was 19 students of class VII-B in SMP Muhammadiyah 10 Surabaya. The instruments used were comparison material test, student performance of observation sheets, and emotional intelligence questionnaires. The results of this study showed that: (1) based on a simple linear regression test, the variable of performance evaluation on learning outcomes, obtained $F_{\text {count }}>F_{\text {table }}$ which was $4.632>4.45$, It means that there is an effect of performance assesment on learning outcomes, that was $42.5 \%$; (2) based on a simple linear regression test of emotional intelligence variables on learning outcomes, it resulted $F_{\text {count }}>F_{\text {table }}$ that is $5.733>$ 4.45, which means that there is an effect of emotional intelligence on learning outcomes, that was $33.6 \%$; (3) based on a multiple linear regression test, the variable of performance assessment and emotional intelligence on learning outcomes obtained $F_{\text {count }}>F_{\text {table }}$ that is $3.672>3.59$, which means that there is an effect of performance assesment on learning outcomes, that was $60.7 \%$. Keywords: performance assessment, emotional intelligence, Project Based Learning (PjBL). 


\section{PENDAHULUAN}

Kegiatan Belajar Mengajar (KBM) tidak terlepas dari perencanaan, pelaksanaan, dan penilaian (Ermawati \& Hidayat, 2017). Jika KBM berlangsung tanpa penilaian, kegiatan tersebut akan kurang berarti. Tanpa penilaian guru tidak dapat mengetahui kemampuan siswa menerima informasi yang telah diberikan. Penilaian dirancang dan dilaksanakan oleh guru sesuai dengan perencanaan dan pelaksanaan pembelajaran. Adapun tujuan penilaian yakni untuk mengetahui kemampuan siswa dalam menerima pembelajaran yang telah diberikan (Mahira, 2017). Salah satu bentuk dari penilaian adalah penilaian kinerja siswa dalam proses pembelajaran.

Menurut Meutia dkk (2013), penilaian kinerja telah banyak diyakini oleh guru dan dapat mencerminkan prestasi siswa dengan lebih akurat dibandingkan penilaian tes tradisional berbentuk pilihan ganda. Menurut Depdiknas, penilaian kinerja adalah penilaian berdasarkan hasil pengamatan penilai terhadap aktivitas siswa sebagaimana yang terjadi (Meutia, Johar, \& Ahmad, 2013). Penilaian dilakukan terhadap unjuk kerja, tingkah laku, atau interaksi siswa. Dengan demikian, penilaian kinerja merupakan salah satu bentuk penilaian alternatif yang menuntut siswa untuk aktif menunjukkan kinerjanya karena yang dinilai tidak hanya hasil akhir tetapi juga proses atau keterampilan, sehingga dapat diketahui pengetahuan dan kemampuan siswa.

Saat ini tidak sedikit sekolah yang masih menggunakan model pembelajaran yang berpusat pada guru (Prasetyawati, 2016), (Abdullah, 2017) (Unengan, Ainy, \& Mursyidah, 2020). Guru hanya memberikan penjelasan dan sedikit melibatkan langsung siswa dalam Kegiatan Belajar Mengajar (KBM). Tentunya pembelajaran ini akan berdampak pada hasil belajar siswa. Siswa terlihat kurang aktif dan mudah bosan. Siswa yang merasa bosan akan sangat sulit mengendalikan diri, mengelola emosi, mengenali emosi orang lain yang disebabkan oleh kurangnya motivasi diri sendiri akan pentingnya prestasi di sekolah yang juga akan berdampak dalam menjaga hubungan dengan orang lain, baik guru maupun teman sejawat (Rohman \& Karimah, 2018).

Selain komponen kinerja terdapat komponen lainnya yang tak kalah penting yaitu kecerdasan emosional siswa. Salah satu hal yang paling merugikan jika mengabaikan segala hal tentang emosi siswa di sekolah yaitu tindakan-tindakan seperti pemukulan terhadap guru, merusak segala bentuk fasilitas umum, mencontek secara terang-terangan, hingga tidak menutup kemungkinan tidak ada lagi rasa malu dalam dirinya ketika siswa melakukan perbuatan tidak terpuji. Termasuk tidak jujur dan merugikan orang lain (Siti \& Suharno , 2010). Siswa harus bisa memanajemen dirinya sendiri agar hubungan dengan orang lain bisa terus berjalan dengan baik. Bagaimanapun, segala aspek tentang sosial mulai dari norma-norma dan nilai-nilai sesuatu yang berhubungan dengan sosial seperti tenggang rasa, hormat pada orang lain, toleransi, gotong royong dan kejujuran menjadi hal yang utama agar terwujudnya suatu tujuan pembelajaran pada pembelajaran. Oleh karena itu, kecerdasan emosional yang apik haruslah dimiliki setiap siswa.

Untuk memunculkan kinerja dan kecerdasan emosional siswa agar mencapai tujuan pembelajaran matematika dibuatkan suatu proyek matematika pada proses pembelajaran. Guru harus memilih strategi pembelajaran, model pembelajaran, dan perangkat pembelajaran yang cocok untuk memunculkan kinerja dan kecerdasan emosional siswa agar dapat dinilai. Menurut 
Solehkhah, dkk (2018) menyatakan bahwa salah satu model pembelajaran yang berbasis proyek dengan menjadikan tugas-tugas berupa permasalahan yang melibatkan siswa dalam aktivitas memecahkan masalah, mengambil keputusan, melakukan investigasi dan refleksi, sehingga guru hanya sebagai fasilitator adalah model pembelajaran Project Based Learning (PjBL).

Berdasarkan uraian permasalahan dilakukan penelitian dengan pengaruh penilaian kinerja dan kecerdasan emosional berdasarkan Project Based Learning (PjBL) terhadap hasil belajar matematika siswa. Adapun tujuan penelitian ini adalah untuk mendeskripsikan pengaruh penilaian kinerja terhadap hasil belajar matematika siswa, untuk mendeskripsikan pengaruh kecerdasan emosional terhadap hasil belajar matematika siswa, untuk mendeskripsikan pengaruh penilaian kinerja dan kecerdasan emosional terhadap hasil belajar matematika siswa.

\section{METODE}

Penelitian ini termasuk pada penelitian kuantitatif dengan desain penelitian korelasi. Sampel pada penelitian ini adalah siswa kelas VII-B SMP Muhammadiyah 10 Surabaya yang berjumlah 19 siswa. Instrumen yang digunakan pada penelitian adalah lembar observasi kinerja siswa, soal tes, dan angket kecerdasan emosional siswa. Pada penelitian ini skema hubungan antar variabel yang digunakan sebagai berikut: (1) Hubungan antara penilaian kinerja $\left(X_{1}\right)$ terhadap hasil belajar siswa (Y); (2) Hubungan antara kecerdasan emosional $\left(X_{2}\right)$ terhadap hasil belajar siswa (Y); (3) Hubungan antara penilaian kinerja $\left(X_{1}\right)$ dan kecerdasan emosional $\left(X_{2}\right)$ terhadap hasil belajar siswa (Y). Teknik pengumpulan data yang digunakan adalah teknik observasi yang digunakan untuk mengetahui kinerja siswa sebagai subjek yang berkaitan dengan masalah penelitian. Teknik observasi dalam penelitian, digunakan dengan tujuan dapat mengamati kejadian-kejadian yang timbul sesuai dengan indikator dalam lembar observasi selama berlangsungnya proses pembelajaran. Selain itu, Teknik tes berupa soal tes dengan bentuk berupa esai yang bertujuan untuk mengetahui kemampuan siswa sesudah tindakan. Adapun angket siswa digunakan untuk mengukur kecerdasan emosional siswa dalam pembelajaran.

Teknik analisis data yang digunakan untuk menguji hipotesis, yaitu:

a. Uji Normalitas

Uji ini digunakan untuk mengetahui data berdistribusi normal atau tidak. Rumus yang digunakan dalam uji normalitas adalah dengan perhitungan Kolmogorov-smirnov.

b. Uji Linearitas

Uji linearitas bertujuan untuk menguji dua variabel mempunyai hubungan yang linear atau tidak. Uji ini digunakan sebagai prasyarat dalam uji regresi linear.

c. Uji Heterokedastisitas

Uji heterokedastisitas bertujuan untuk menguji terjadi ketidaksamaan variance dari residual satu pengamatan ke pengamatan lain dalam model regresi atau tidak. Jika variance dari residual satu pengamatan ke pengamatan lain tetap maka disebut homokedastisitas dan jika berbeda disebut heterokedatissitas. Model regresi yang baik adalah homokedastisitas.

d. Uji Regresi Linear sederhana

Uji ini merupakan teknik analisis data statistik untuk mengetahui pengaruh masingmasing variabel bebas terhadap variabel terikat, yaitu: 
92 | Nanly O. P. H. Biantoro, Febriana Kristanti, Himmatul Mursyidah-Pengaruh Penilaian Kinerja dan Kecerdasan Emosional ....

1) Pengaruh Penilaian Kinerja $\left(X_{1}\right)$ terhadap Hasil Belajar Siswa $(Y)$.

2) Pengaruh Kecerdasan Emosional $\left(X_{2}\right)$ terhadap Hasil Belajar Siswa $(Y)$.

e. Uji Regresi Linear Berganda

Uji regresi linear berganda untuk mengetahui bagaimana pengaruh antara dua variabel bebas terhadap satu variabel terikat, yaitu pengaruh penilaian kinerja dan kecerdasan emosional terhadap hasil belajar siswa berdasarkan PjBL.

\section{HASIL DAN PEMBAHASAN}

Data yang diperoleh dari penelitian ini adalah data kuantitatif dari hasil pengamatan lembar observasi kinerja siswa, soal tes materi perbandingan, dan angket kecerdasan emosional siswa. Pengolahan data kuantitatif dilakukan dengan bantuan software SPSS versi 22.0 for windows. Data-data tersebut sebagai berikut.

a. Data Lembar Observasi Kinerja Siswa

Lembar observasi kinerja siswa berfungsi untuk mengamati segala aktivitas yang diakukan oleh siswa selama proses pembelajaran belangsung dengan mengisi kolom yang sudah disediakan dan berdasarkan pedoman rubrik pada Tabel 1.

Tabel 1. Rubrik untuk Penilaian Kinerja Berbasis Proyek

\begin{tabular}{|c|c|}
\hline Tingkat Pencapaian dan Skor & Deskripsi \\
\hline Istimewa (4) & $\begin{array}{l}\text { Siswa menunjukkan kinerja yang sangat baik, konsisten } \\
\text { dan terus berusaha untuk meningkatkan kinerjanya. }\end{array}$ \\
\hline Baik (3) & $\begin{array}{l}\text { Siswa menunjukkan kinerja yang baik dan berusaha } \\
\text { meningkatkannya secara umum }\end{array}$ \\
\hline Cukup (2) & $\begin{array}{l}\text { Siswa hanya menunjukkan sedikit kinerja yang baik } \\
\text { dengan beberapa kinerja yang kurang konsisten. }\end{array}$ \\
\hline Kurang (1) & $\begin{array}{l}\text { Kinerja yang ditunjukkan siswa kurang baik dan tidak } \\
\text { berusaha meningkatkan kinerjanya }\end{array}$ \\
\hline Sangat Kurang (0) & $\begin{array}{l}\text { Tidak ada upaya sama sekali untuk menampilkan } \\
\text { kemajuan dalam pencapaian tujuan }\end{array}$ \\
\hline
\end{tabular}

Berdasarkan rubrik pada Tabel 1, diperoleh data hasil observasi kinerja siswa pada kelas penelitian. Tabel 2 memuat data hasil observasi kinerja siswa yang telah diamati dalam kegiatan proyek pada tahap persiapan, pelaksanaan, dan pelaporan.

b. Data Soal Tes Materi Perbandingan

Soal tes materi perbandingan diberikan setelah pelaksanaan pembelajaran telah selesai. Soal tes tersebut berguna untuk mengetahui pemahaman siswa setelah diberikan treatment khusus pada proses pembelajaran dengan berisikan tiga butir soal. Pada Tabel 3 diberikan data hasil soal tes materi perbandingan pada kelas penelitian.

c. Data Angket Kecerdasan Emosional

Angket kecerdasan emosional diberikan setelah soal tes materi perbandingan telah selesai. Angket tersebut berisikan 33 pernyataan yang harus dijawab oleh siswa sesuai pada Tabel 4. 
Tabel 2. Data Observasi Kinerja Siswa pada Kelas Penelitian

\begin{tabular}{cc}
\hline No. Absen & $\begin{array}{c}\text { Nilai Kinerja Kelas } \\
\text { Penelitian }\end{array}$ \\
\hline 1 & 89 \\
2 & 89 \\
3 & 89 \\
4 & 89 \\
5 & 75 \\
6 & 85 \\
7 & 75 \\
8 & 78 \\
9 & 75 \\
10 & 60 \\
11 & 60 \\
12 & 82 \\
13 & 78 \\
14 & 82 \\
15 & 82 \\
16 & 75 \\
17 & 100 \\
18 & 96 \\
19 & 78 \\
\hline
\end{tabular}

Tabel 3. Data Hasil Tes Kelas Penelitian

\begin{tabular}{cc}
\hline No. Absen & Nilai Tes Kelas Penelitian \\
\hline 1 & 89 \\
2 & 95 \\
3 & 90 \\
4 & 70 \\
5 & 60 \\
6 & 95 \\
7 & 90 \\
8 & 70 \\
9 & 75 \\
10 & 80 \\
11 & 85 \\
12 & 80 \\
13 & 89 \\
14 & 85 \\
16 & 90 \\
17 & 78 \\
18 & 90 \\
19 & 95 \\
20 & 70 \\
\hline
\end{tabular}

Tabel 4. Pertanyaan pada Angket Kecerdasan Emosional

No

\begin{tabular}{ll}
\hline 1. & Saya mengetahui penyebab yang membuat saya malas belajar \\
\hline 2. & Saya tahu ketika saya sedang marah \\
\hline 3. & Saya merasa sedih jika mendapat nilai ulangan saya buruk \\
\hline 4. & Saya tidak merasa sedih jika mendapat nilai ulangan saya buruk \\
\hline 5. & Saya menyadari bahwa perasaan malu untuk bertanya dapat menyulitkan saya dalam belajar \\
\hline 6. & saya mudah marah ketika saya sedang kelelahan \\
\hline 7. & Saya berlapang dada ketika keinginan saya tidak terpenuhi \\
\hline 8. & Saya terlalu gegabah dalam melakukan sesuatu \\
\hline 9. & Saya berfikir terlebih dahulu sebelum bertindak \\
\hline 10. & Saya selalu berbagi kebahagiaan pada saat saya bahagia \\
\hline 11. & Saya bersikap terbuka pada saat ada masalah \\
\hline 12. & Saya menanggapi kegagalan sebagai proses menuju keberhasilan \\
\hline 13. & Saya merasa bahwa kegagalan adalah akhir dari usaha saya \\
\hline 14. & Saya tidak suka berlarut-larut dalam masalah \\
\hline 15. & Saya segera bangkit ketika saya gagal \\
\hline 16. & Saya selalu berusaha agar masuk dalam peringkat 10 besar di kelas saya \\
\hline 17. & Saya tidak mempunyai semangat untuk berkompetisi dengan teman saya dalam hal pelajaran \\
\hline 18. & Saya selalu berusaha agar mendapat nilai yang baik diantara teman-teman saya \\
\hline 19. & Saya menyadari kelemahan saya dalam belajar di sekolah dan berusaha meningkatkannya dengan belajar di rumah \\
\hline 20. & Saya bersedia dengan senang hati mendengarkan keluh kesah orang lain \\
\hline 21. & Saya menghormati teman yang sedang presentasi di depan kelas \\
\hline 22. & Saya dapat mengetahui bagaimana perasaan orang lain terhadap saya \\
\hline 23. & Saya dapat menerima pendapat orang lain walau berbeda dengan saya \\
\hline 24. & Saya menerima dengan lapang dada kritik dan saran yang diberikan orang lain \\
\hline 25. & Saya marah jika seseorang mengkritik saya \\
\hline 26. & Saya bahagia ketika teman saya berprestasi \\
\hline 27. & Saya iri ketika melihat teman saya berprestasi \\
\hline 28. & Saya dapat berkerja dalam kelompok \\
\hline 29. & Saya dapat menyesuaikan diri dengan tujuan kelompok \\
\hline 30. & Saya mudah bergaul dengan teman yang berbeda kelas \\
\hline 31. & Saya tidak ragu memulai pembicaraan dengan orang yang baru saya kenal \\
\hline 32. & Ketika saya salah, saya akan meminta maaf tanpa malu mengatakannya \\
\hline 33. & Saya tidak akan pernah meminta maaf pada siapapun walau saya yang salah \\
\hline & \\
\hline
\end{tabular}

Pernyataan 
Berdasarkan pernyataan pada Tabel 4, diperoleh data hasil angket kecerdasan emosional siswa. Kemudian, dilakukan analisis data untuk menguji hipotesis yang telah dibuat.

a. Uji Normalitas

Sebelum menguji hipotesis yang diajukan dalam penelitian ini, peneliti terlebih dahulu menguji kenormalan (normalitas) data dengan uji normalitas kolmogorov-smirnov melalui SPSS 22.0 for windows. Uji normalitas dilakukan terhadap nilai kinerja siswa $\left(X_{1}\right)$, kecerdasan emosional siswa $\left(X_{2}\right)$ dan hasil belajar siswa $(Y)$. Hasil uji normalitas ditunjukan pada Tabel 5.

\begin{tabular}{|c|c|c|c|c|}
\hline \multicolumn{5}{|c|}{$\begin{array}{c}\text { Tabel 5. Uji Normalitas Data Hasil Penelitian } \\
\text { One-Sample Kolmogorov-Smirnov Test }\end{array}$} \\
\hline & & $\mathrm{X} 1$ & $\mathrm{X} 2$ & $\mathrm{Y}$ \\
\hline \multicolumn{2}{|l|}{$\mathrm{N}$} & 19 & 19 & 19 \\
\hline \multirow[t]{2}{*}{ Normal Parameters ${ }^{\mathrm{a}, \mathrm{b}}$} & Mean & 80.89 & 82.95 & 87.47 \\
\hline & Std. Deviation & 10.311 & 4.564 & 4.142 \\
\hline \multirow[t]{3}{*}{ Most Extreme Differences } & Absolute & .179 & .146 & .134 \\
\hline & Positive & .111 & .146 & .134 \\
\hline & Negative & -.179 & -.139 & -.100 \\
\hline Test Statistic & & .179 & .146 & .134 \\
\hline Asymp. Sig. (2-tailed) & & .113 & .200 & .200 \\
\hline
\end{tabular}

Berdasarkan Tabel 5 terlihat bahwa dengan menggunakan SPSS 22.0 diperoleh $K S_{\text {hitung }}\left(X_{1}\right)$ adalah $0,179, K S_{\text {hitung }}\left(X_{2}\right)$ adalah 0,146 , dan $K S_{\text {hitung }}(Y)$ adalah 0,134 . Selanjutnya dalam pengujian hipotesis didapat $K S_{\text {tabel }}$ yaitu 0,30142. Maka dapat disimpulkan bahwa masing-masing variabel $K S_{\text {hitung }}$ kurang dari $K S_{\text {tabel }}$, sehingga $H_{0}$ diterima dan data penelitian berdistribusi normal.

b. Uji Linearitas

Hasil perhitungan dengan menggunakan SPSS 22.0 diperoleh output dari analisis uji linearitas dan disajikan pada Tabel 6.

Tabel 6. Uji Linearitas Variabel $X_{1}$ dengan $Y$

\begin{tabular}{|c|c|c|c|c|c|c|c|}
\hline \multicolumn{8}{|c|}{ ANOVA Table } \\
\hline & & & $\begin{array}{l}\text { Sum of } \\
\text { Squares }\end{array}$ & Df & $\begin{array}{c}\text { Mean } \\
\text { Square }\end{array}$ & $\mathrm{F}$ & Sig. \\
\hline \multirow[t]{5}{*}{$\mathrm{Y} * \mathrm{X} 1$} & \multirow[t]{3}{*}{ Between Groups } & $\begin{array}{l}\text { (Combine } \\
\text { d) }\end{array}$ & 38.570 & 7 & 5.510 & .224 & .971 \\
\hline & & Linearity & 19.273 & 1 & 19.273 & .785 & .395 \\
\hline & & $\begin{array}{l}\text { Deviation } \\
\text { from } \\
\text { Linearity }\end{array}$ & 19.297 & 6 & 3.216 & $\begin{array}{r}3.73 \\
1\end{array}$ & .989 \\
\hline & Within Groups & & 270.167 & 11 & 24.561 & & \\
\hline & Total & & 308.737 & 18 & & & \\
\hline
\end{tabular}

Berdasarkan Tabel 6 diperoleh bahwa nilai Sig $=0,989>0,05$ dan nilai $F_{\text {hitung }}=$ $3,731<F_{\text {tabel }}=3,63$. Dapat disimpulkan bahwa ada hubungan yang linear antara variabel $X_{1}$ dengan $Y$. 
Tabel 7. Uji Linearitas Variabel $X_{2}$ dengan $Y$ ANOVA Table

\begin{tabular}{lllrrrrr}
\hline & & Sum of Squares & df & Square & F & Sig. \\
\hline $\mathrm{Y} * \mathrm{X} 2$ & Between Groups & $\begin{array}{l}\text { (Combine } \\
\text { d) }\end{array}$ & 194.487 & 10 & 19.449 & 1.362 & .338 \\
& $\begin{array}{l}\text { Linearity } \\
\text { Deviation } \\
\text { from }\end{array}$ & 4.167 & 1 & 4.167 & .292 & .604 \\
& Linearity & 190.320 & 9 & 21.147 & 3.481 & .296 \\
Within Groups & & 114.250 & 8 & 14.281 & & \\
Total & 308.737 & 18 & & & & \\
\hline
\end{tabular}

Berdasarkan Tabel 7 diperoleh bahwa nilai $\operatorname{Sig}=0,296>0,05$ dan nilai $F_{\text {hitung }}=$ $3,481<F_{\text {tabel }}=3,63$. Sehingga dapat disimpulkan bahwa ada hubungan yang linear antara variabel $X_{2}$ dengan $Y$.

c. Uji Heterokedastisitas

Setelah dilakukan uji linearitas, kemudian dilakukan uji heterokedastisitas pada data hasil penelitian. Hasil perhitungan uji heterokedastisitas metode GLEJSER dengan bantuan SPSS 22.0 diberikan pada Tabel 8.

Tabel 8. Hasil Uji Heterokedastisitas Coefficients

\begin{tabular}{llrrrrrr}
\hline & & \multicolumn{2}{c}{$\begin{array}{l}\text { Unstandardized } \\
\text { Coefficients }\end{array}$} & \multicolumn{2}{c}{$\begin{array}{c}\text { Standardized } \\
\text { Coefficients }\end{array}$} & & \\
\cline { 3 - 5 } Model & & \multicolumn{1}{c}{ B } & Std. Error & Beta & \multicolumn{1}{c}{ T } & \multicolumn{1}{c}{ Sig. } \\
\hline 1 & (Constant) & 18.268 & 12.192 & & & 1.498 & .154 \\
& X1 & -.064 & .059 & -.257 & -1.089 & .292 \\
& X2 & -.122 & .134 & -.216 & -.914 & .375 \\
\hline
\end{tabular}

a. Dependent Variable: RES2

Berdasarkan Tabel 8, diperoleh nilai Sig pada masing-masing variabel yaitu 0,292 dan 0,375 lebih besar dari 0,05 . Hal ini menunjukan bahwa tidak terjadi heterokedastisitas pada penelitian yang dilakukan. Artinya variabel dalam penelitian ini homokedastisitas. Model regresi yang baik adalah homokedastisitas.

d. Analisis Regresi Linear Sederhana

1) Uji Regresi Linear Sederhana Penilaian Kinerja $\left(X_{1}\right)$ terhadap Hasil Belajar $(Y)$

Hasil output uji regresi linear sederhana dengan menggunakan SPSS 22.0 untuk mengetahui hubungan penilaian kinerja dengan hasil belajar seperti pada Tabel 9 .

Tabel 9. Hasil Output 1 Uji Regresi Linear Sederhana $X_{1}$ dengan $Y$ Model Summary

\begin{tabular}{lccccc}
\hline Model & $\mathrm{R}$ & R Square & $\begin{array}{c}\text { Adjusted R } \\
\text { Square }\end{array}$ & $\begin{array}{c}\text { Std. Error of the } \\
\text { Estimate }\end{array}$ \\
\hline 1 & $.250^{\mathrm{a}}$ & .425 & .007 & & 4.126 \\
\hline
\end{tabular}

a. Predictors: (Constant), X1

Pada Tabel 9, korelasi antara variabel dependen dengan variabel indepeden bersifat positif sebesar 0.250 , artinya jika nilai $X_{1}$ naik, maka akan berhubungan dengan kenaikan nilai $Y$ sebesar 25\%. $R$ Square disebut juga dengan koefisien determinasi, nilai $R$ square sebesar 0,425 , artinya bahwa $42,5 \%$ variasi dari hasil 
belajar dapat disebabkan oleh faktor penilian kinerja. Sedangkan sisanya (100 - 42,5 $=57,5)$ atau $57,5 \%$ disebabkan oleh faktor yang lain. Std. error of the Estimate yang bernilai 4,126 merupakan kesalahan standar yang menggambarkan tingkat keakuratan prediksi regresi, dimana semakin kecil nilainya maka semakin akurat prediksinya.

Tabel 10. Hasil Output 2 Uji Regresi Linear Sederhana $X_{1}$ dengan $Y$

\begin{tabular}{|c|c|c|c|c|c|c|}
\hline \multicolumn{7}{|c|}{ ANOVA $^{a}$} \\
\hline Model & & Sum of Squares & Df & Mean Square & $\mathrm{F}$ & Sig. \\
\hline \multirow[t]{3}{*}{1} & Regression & 19.273 & 1 & 19.273 & 4.632 & $.032^{\mathrm{b}}$ \\
\hline & Residual & 289.464 & 17 & 17.027 & & \\
\hline & Total & 308.737 & 18 & & & \\
\hline \multicolumn{6}{|c|}{ a. Dependent Variable: Y } & b. Predictors: (Constant), X1 \\
\hline
\end{tabular}

Berdasarkan Tabel 10, nilai $F_{\text {hitung }}$ sebesar 4,632. Nilai tersebut akan dibandingan dengan nilai pada $F_{\text {tabel }}$, dengan $d b_{1}=k$ (banyaknya variabel bebas) dan $d b_{2}=n-$ $k$ sehingga $d b_{2}=19-2=17$. Maka nilai $F_{\text {tabel }}$ yaitu 4,45 dengan taraf signifikansi $5 \%$. Selanjutnya pengujian hipotesis, kriteria untuk menolak dan tidak menolak berdasarkan kriteria khusus yaitu, $F_{\text {hitung }}>F_{\text {tabel }}$, maka $H_{0}$ diterima. Nilai $F_{\text {hitung }}>$ $F_{\text {tabel }}$, artinya terdapat pengaruh dari variabel $X_{1}$ terhadap variabel $Y$.

Tabel 11. Hasil Output 3 Uji Regresi Linear Sederhana $X_{1}$ dengan $Y$ Coefficients $^{\mathrm{a}}$

\begin{tabular}{llrrrrr}
\hline & \multicolumn{2}{c}{ Unstandardized } & \multicolumn{2}{c}{ Standardized } \\
Coefficients & \multicolumn{2}{c}{ Coefficients } & & \\
Model & & \multicolumn{1}{c}{ B } & Std. Error & Beta & \multicolumn{1}{c}{ T } & \multicolumn{1}{c}{ Sig. } \\
\hline 1 & (Constant) & 45.592 & 7.689 & & 12.432 & .000 \\
& X1 & .100 & .094 & .250 & 1.064 & .302 \\
\hline
\end{tabular}

a. Dependent Variable: Y

Pada bagian output 3 Tabel 11 menggambarkan seberapa berapa besar koefisiensi regresi.

(a) Bentuk persamaan regresi sederhana antara $X_{1}$ dan $Y$ :

$$
\widehat{Y}=46,592+0,100 X_{1}
$$

(b) Konstanta sebesar 46,592 menyatakan bahwa jika siswa tidak memunculkan kinerja dalam proses pembelajaran, maka hasil belajar siswa sebesar 46,592.

(c) Koefisien regresi 0,100 menunjukan bahwa setiap kinerja $\left(X_{1}\right)$ bertambah +1 , maka hasil belajar juga akan bertambah sebesar 0,100 poin.

Berdasarkan hasil analisis regresi linear sederhana terdapat pengaruh penilaian kinerja $\left(X_{1}\right)$ terhadap hasil belajar $(Y)$. Hal tersebut terlihat bahwa terdapat pengaruh yang positif dan signifikan antara penilaian kinerja siswa terhadap hasil belajar matematika siswa sebesar 42,5\%. Pengaruh penilaian kinerja siswa dapat meningkatkan hasil belajar hingga 25\%. Hal ini disebabkan oleh model pembelajaran project based learning $(\mathrm{PjBL})$ yang mengutamakan kinerja siswa selama pembelajaran berlangsung.

PjBL merupakan model pembelajaran berbasis proyek yang menggunakan masalah real sebagai suatu konteks bagi siswa untuk belajar tentang cara berpikir kritis, bekerja secara kolaboratif, dan keterampilan memecahkan masalah sebagai 
tantangan serta mengelola waktunya sendiri untuk menyelesaikan atau menghasilkan suatu proyek. Oleh karena itu, dibuat suatu rancangan proyek yang dipakai pada proses pembelajaran dan juga dapat memunculkan kinerja yang dimiliki oleh setiap siswa. Proyek tersebut adalah "Jika aku menjadi seorang arsitek". Kemudian dilakukan pengamatan pada saat proses pembelajaran berbasis proyek berlangsung. Instrumen yang digunakan pada saat mengobservasi kegiatan siswa adalah lembar observasi kinerja siswa berbasis proyek yang di dalamnya terdapat indikator-indikator yang diadaptasi dari penelitian Wulan (2008) tentang penilaian kinerja pada saat tahap persiapan, tahap pelaksanaan dan tahap pelaporan guna untuk menjadi pedoman observer dalam hal-hal apa saja yang harus diamati pada penilaian kinerja.

Indikator-indikator tersebut antara lain, pada tahap persiapan yaitu kesiapan alat dan bahan yang akan digunakan dalam menyelesaikan proyek, pada tahap pelaksanaan yaitu cara menggunakan alat dengan benar, proses mengumpulkan data yang akan dibutuhkan, menggunakan konsep yang tepat untuk menyelesaikan permasalahan pada proyek, serta pada tahap pelaporan yaitu ketepatan isi laporan dan bentuk sajian laporan serta presentasi. Indikator-indikator yang digunakan dalam penelitian ini sudah diadaptasi dari penelitian sebelumnya yaitu penelitian yang dilakukan oleh Wulan (2008) untuk mata pelajaran biologi sehingga indikator-indikator tersebut cocok dan digunakan pada penelitian ini.

2) Uji Regresi Linear Sederhana Kecerdasan Emosional $\left(X_{2}\right)$ terhadap Hasil Belajar $(Y)$

Hasil uji regresi linear sederhana dengan bantuan SPSS 22.0 untuk mengetahui hubungan kecerdasan emosional terhadap hasil belajar seperti pada Tabel 12.

Tabel 12. Hasil Output 1 Uji Regresi Linear Sederhana $X_{2}$ dengan $Y$ Model Summary

\begin{tabular}{lccrr}
\hline Model & $\mathrm{R}$ & R Square & $\begin{array}{c}\text { Adjusted R } \\
\text { Square }\end{array}$ & $\begin{array}{c}\text { Std. Error of the } \\
\text { Estimate }\end{array}$ \\
\hline 1 & $.216^{\mathrm{a}}$ & .336 & -.045 & 4.233 \\
\hline a. Predictors: (Constant), X2 & & & &
\end{tabular}

Pada Tabel 12, korelasi antar variabel dependen dengan variabel indepeden bersifat positif sebesar $21,6 \%$, artinya jika nilai $X_{2}$ naik, maka akan berhubungan dengan kenaikan nilai $Y$ sebesar 21,6\%. $R$ Square disebut juga dengan koefisien determinasi, nilai $R$ square sebesar 0,336 , artinya bahwa $33,6 \%$ variasi dari hasil belajar dapat disebabkan oleh faktor kecerdasan emosional. Sedangkan sisanya (100$33,6=66,4)$ atau $66,4 \%$ disebabkan oleh faktor yang lain. Std. error of the Estimate yang bernilai 4,233 merupakan kesalahan standar yang menggambarkan tingkat keakuratan prediksi regresi, dimana semakin kecil nilainya maka semakin akurat prediksinya.

Tabel 13. Hasil Output 2 Uji Regresi Linear Sederhana $X_{2}$ dengan $Y$

\begin{tabular}{llrrrrr}
\multicolumn{7}{c}{ ANOVA $^{\mathrm{a}}$} \\
\hline Model & & Sum of Squares & \multicolumn{1}{c}{ df } & Mean Square & F & \multicolumn{1}{c}{ Sig. } \\
\hline 1 & Regression & 4.167 & 1 & 4.167 & 5.733 & $.046^{\mathrm{b}}$ \\
& Residual & 304.570 & 17 & 17.916 & & \\
& Total & 308.737 & 18 & & & \\
\hline
\end{tabular}

a. Dependent Variable: Y

b. Predictors: (Constant), X2 
Berdasarkan Tabel 13, nilai $F_{\text {hitung }}$ sebesar 5,733. Nilai tersebut akan dibandingan dengan nilai pada $F_{\text {tabel }}$, dimana $d b_{1}=k$ (banyaknya variabel bebas) dan $d b_{2}=n-k$ sehingga $d b_{2}=19-2=17$. Sehingga nilai $F_{\text {tabel }}$ yaitu 4,45 dengan taraf signifikansi 5\%. Selanjutnya pengujian hipotesis, kriteria untuk menolak dan tidak menolak berdasarkan kriteria khusus yaitu, $F_{\text {hitung }}>F_{\text {tabel }}$, maka $H_{0}$ diterima. Nilai $F_{\text {hitung }}>F_{\text {tabel }}$, artinya terdapat pengaruh dari variabel $X_{1}$ terhadap variabel $Y$ dan terdapat pengaruh dari variabel $X_{2}$ terhadap variabel $Y$.

Tabel 14. Hasil Output 3 Uji Regresi Linear Sederhana $X_{2}$ dengan $Y$ Coefficients $^{\mathrm{a}}$

\begin{tabular}{llrrrrr}
\hline & \multicolumn{7}{c}{ Unstandardized Coefficients } & \multicolumn{2}{c}{$\begin{array}{c}\text { Standardized } \\
\text { Coefficients } \\
\text { Model }\end{array}$} & \multicolumn{1}{c}{ B } & Std. Error & Beta & \multicolumn{1}{c}{ T } & \multicolumn{1}{c}{ Sig. } \\
\hline 1 & (Constant) & 46.218 & 18.158 & & 5.299 & .000 \\
& X2 & .105 & .219 & .116 & .482 & .636 \\
\hline
\end{tabular}

a. Dependent Variable: Y

Pada bagian Output 3 Tabel 14 menggambarkan seberapa besar koefisiensi regresi.

1) Bentuk persamaan regresi linear sederhana antara $X_{2}$ dengan $Y$

$$
\hat{Y}=46,218+0,105 X_{1}
$$

2) Konstanta sebesar 46,218 menyatakan bahwa jika siswa tidak memunculkan kinerja dalam proses pembelajaran maka hasil belajar siswa sebesar 46,218.

3) Koefisien regresi 0,105 menunjukan bahwa setiap kecerdasan emosional $\left(X_{2}\right)$ bertambah +1 , maka hasil belajar juga akan bertambah sebesar 0,105 poin.

Berdasarkan hasil uji regresi sederhana antara kecerdasan emosional $\left(X_{2}\right)$ terhadap hasil belajar $(Y)$, ada pengaruh yang positif dan signifikan antara kecerdasan emosional siswa terhadap hasil belajar matematika siswa sebesar 33,6\%. Pengaruh kecerdasan emosional siswa dapat meningkatkan hasil belajar hingga 21,6\%. Hal ini disebabkan karena pada salah satu karakteristik model PjBL harus dapat bekerja secara kolaboratif dan bisa mengelola waktunya sendiri untuk menyelesaikan atau menghasilkan produk. Pada saat itulah siswa akan memunculkan kecerdasan emosionalnya.

Kemunculan kecerdasan emosional ini mempunyai kategori-kategori yang berbeda, diantaranya mengenali emosi diri, mengelola emosi, memotivasi diri sendiri, mengenali emosi orang lain dan membina hubungan dengan orang lain. Sebagaimana yang tercantum dalam bukunya "Emtional Intellegence" oleh Goleman (2016), yang mengkategorikan kecerdasan emosional menjadi aspek-aspek sebagai berikut: kesadaran diri, mengelola emosi, memanfaatkan emosi secara produktif, empati dan membina hubungan. Berdasarkan observasi dalam angket kecerdasan emosional siswa, siswa mempunyai kecerdasan emosional yang baik dan mencangkup semua aspek yang ada pada teori Goleman, otomatis dalam kelompok ia akan bersahabat dengan semua anggota kelompok. Tidak memaksakan kehendak, tidak mementingkan kepentingan sendiri, saling tolong-menolong, toleransi, dan saling mendukung untuk mencapai tujuan bersama-sama dengan sebaik-baiknya. Secara tidak langsung mereka 
akan melakukan proyek yang diberikan dengan sangat baik, agar dapat memecahkan masalah yang terdapat pada proyek tersebut. Terbukti kecerdasan emosional berdasarkan PjBL berpengaruh terhadap hasil belajar matematika siswa. Penelitian serupa telah dilakukan oleh Iwanina Hidanah pada tahun 2016 dengan judul "Hubungan antara kecerdasan emosional dengan hasil belajar PKn siswa IV SDN Gunung Pati Semarang" yang menyatakan ada hubungan yang signifikan antara kecerdasan emosional dengan hasil belajar. Hal yang membedakan penelitian ini dengan penelitian sebelumnya adalah penelitian ini menggunakan model pembelajaran PjBL atau Project Based Learning yang bertujuan untuk memunculkan kecerdasan emosional siswa dalam mengerjakan proyek yang telah diberikan.

e. Analisis Regresi Linear Ganda Penilaian Kinerja $\left(X_{1}\right)$ dan Kecerdasan Emosional $\left(X_{2}\right)$ Terhadap Hasil Belajar $(Y)$

Hasil output uji regresi linear ganda dengan menggunakan SPSS 22.0 untuk mengetahui hubungan penilaian kinerja dan kecerdasan emosional terhadap hasil belajar siswa ditunjukan pada Tabel 15.

Tabel 15. Hasil Output 1 Uji Regresi Linear Ganda Model Summary

\begin{tabular}{|c|c|c|c|c|}
\hline Model & $\mathrm{R}$ & R Square & $\begin{array}{l}\text { Adjusted R } \\
\text { Square }\end{array}$ & $\begin{array}{l}\text { Std. Error of the } \\
\text { Estimate }\end{array}$ \\
\hline 1 & $.278^{a}$ & .607 & .038 & 4.219 \\
\hline
\end{tabular}

Berdasarkan Tabel 15, diperoleh korelasi antar variabel dependen dengan variabel indepeden bersifat positif sebesar 0.278 , artinya jika nilai $X_{1}$ dan $X_{2}$ naik, maka akan berhubungan dengan kenaikan nilai $Y$ sebesar 27,8\%. $R$ Square disebut juga dengan koefisien determinasi, nilai $R$ square sebesar 0,607 , artinya bahwa $60,7 \%$ variasi dari hasil belajar dapat disebabkan oleh faktor penilian kinerja dan kecerdasan emosional. Sedangkan sisanya $(100-60,7=39,3)$ atau 39,3\% disebabkan oleh faktor yang lain. Std. error of the Estimate yang bernilai 4,219 merupakan kesalahan standar yang menggambarkan tingkat keakuratan prediksi regresi, artinya semakin kecil nilainya maka semakin akurat prediksinya.

Tabel 16. Hasil Output 2 Uji Regresi Linear Ganda

\begin{tabular}{llrrrrr}
\multicolumn{6}{c}{ ANOVA $^{\text {a }}$} \\
\hline Model & & Sum of Squares & df & Mean Square & F & Sig. \\
\hline 1 & Regression & 23.924 & 2 & 11.962 & 3.672 & $.425^{\text {b }}$ \\
& Residual & 284.813 & 16 & 17.801 & & \\
& Total & 308.737 & 18 & & & \\
\hline
\end{tabular}

a. Dependent Variable: Y

b. Predictors: (Constant), X1, X2

Berdasarkan Tabel 16, diperoleh nilai $F_{\text {hitung }}$ sebesar 3,672. Nilai tersebut akan dibandingan dengan nilai pada $F_{\text {tabel }}$, dimana $d b_{1}=k$ (banyaknya variabel bebas) dan $d b_{2}=n-k$ sehingga $d b_{2}=19-2=17$. Maka nilai $F_{\text {tabel }}$ yaitu 3,59 dengan taraf signifikansi 5\%. Selanjutnya pengujian hipotesis, kriteria untuk menolak dan tidak menolak berdasarkan kriteria khusus yaitu, $F_{\text {hitung }}>F_{\text {tabel }}$, maka $H_{0}$ diterima. 
Nilai $F_{\text {hitung }}>F_{\text {tabel }}$, artinya terdapat pengaruh dari variabel $X_{1}$ dan variabel $X_{2}$ terhadap variabel $Y$.

Tabel 17. Hasil Output 3 Uji Regresi Linear Ganda Coefficients

\begin{tabular}{|c|c|c|c|c|c|}
\hline \multirow[b]{2}{*}{ Model } & \multicolumn{2}{|c|}{ Unstandardized Coefficients } & \multicolumn{2}{|l|}{$\begin{array}{l}\text { Standardized } \\
\text { Coefficients }\end{array}$} & \multirow[b]{2}{*}{ Sig. } \\
\hline & B & Std. Error & Beta & $\mathrm{T}$ & \\
\hline$\overline{\text { (Constant) }}$ & 34.937 & 19.902 & & 5.273 & .000 \\
\hline $\mathrm{X} 2$ & .111 & .218 & .123 & .511 & .616 \\
\hline $\mathrm{X} 1$ & .102 & .096 & .253 & 1.054 & .308 \\
\hline
\end{tabular}

Pada bagian Output 3 Tabel 17 menggambarkan seberapa berapa besar koefisiensi regresi.

1) Bentuk persamaan regresi linear berganda antara $X_{1}$ dan $X_{2}$ terhadap $Y$.

$$
\hat{Y}=34,937+0,111 X_{1}+0,102 X_{2}
$$

2) Konstanta sebesar 34,937 menyatakan bahwa jika siswa tidak memunculkan kinerja dan kecerdasan emosional yang baik dalam proses pembelajaran maka hasil belajar siswa sebesar 46,218.

3) Koefisien regresi 0,111 menunjukan bahwa setiap penilaian kinerja $\left(X_{1}\right)$ bertambah +1 , maka hasil belajar juga akan bertambah sebesar 0,111 poin

4) Koefisien regresi 0,102 menunjukan bahwa setiap kecerdasan emosional $\left(X_{2}\right)$ bertambah +1 , maka hasil belajar juga akan bertambah sebesar 0,102 poin

Berdasarkan analisis regresi linear ganda penilaian kinerja $\left(X_{1}\right)$ dan kecerdasan emosional $\left(X_{2}\right)$ terhadap hasil belajar $(Y)$ berdasarkan model pembelajaran PjBL mampu membuat kinerja dan kecerdasan emosional siswa mempengaruhi hasil belajar matematika siswa. Hal tersebut ditunjukan dengan adanya pengaruh yang positif dan signifikan antara penilaian kinerja siswa dan kecerdasan emosional siswa terhadap hasil belajar matematika siswa sebesar $60,7 \%$. Pengaruh kecerdasan emosional siswa dapat meningkatkan hasil belajar hingga 27,8\%. Hal tersebut ditunjukkan jika siswa memiliki kecerdasan emosional yang baik mereka akan dapat mengendalikan diri mereka sendiri dan tentunya akan menunjukan segala apapun yang mereka bisa pada proyek ini dengan kata lain mereka akan menunjukan kinerja terbaik mereka sendiri untuk menyelesai permasalahan proyek yang diberikan. Terbukti secara tidak langsung juga akan mempengaruhi hasil belajar matematika siswa.

Berdasarkan hasil koefisien regresi pada uji regresi linear sederhana variabel penilaian kinerja terhadap hasil belajar yaitu 0,100 lebih kecil dari hasil koefisien regresi pada uji regresi linear berganda variabel penilaian kinerja dan kecerdasan emosional terhadap hasil belajar yaitu 0,111. Hal tersebut menunjukan bahwa siswa yang memiliki kinerja yang tinggi belum tentu mempunyai kecerdasan emosional yang tinggi juga. Begitu juga dengan hasil koefisien regresi pada uji regresi linear sederhana variabel kecerdasan emosional terhadap hasil belajar yaitu 0,105 lebih besar dari hasil koefisien regresi pada uji linear berganda variabel penilaian kinerja dan kecerdasan emosional terhadap hasil belajar yaitu 0,102 . Hal tersebut menunjukan bahwa siswa yang memiliki kecerdasan emosional yang tinggi belum tentu mempunyai kinerja yang tinggi juga. Pada penelitian-penelitian 
sebelumnya belum ada yang membahas tentang pengaruh penilaian kinerja dan kecerdasan emosional berdasarkan PjBL terhadap hasil belajar matematika siswa. Diharapkan penelitian ini dapat membantu peneliti lain yang meneliti kesamaan topik.

\section{SIMPULAN}

Berdasarkan hasil penelitian dan hasil pembahasan dapat dijawab dari rumusan masalah yang telah dilakukan oleh peneliti mengenai pengaruh penilaian kinerja dan kecerdasan emosional berdasarkan PjBL terhadap hasil belajar matematika siswa pada kelas VII SMP Muhammadiyah 10 Surabaya, disimpulkan sebagai berikut.

a. Berdasarkan analisa data penilaian kinerja siswa selama proses pembelajaran dapat disimpulkan bahwa terdapat pengaruh yang positif dan signifikan antara penilaian kinerja siswa terhadap hasil belajar matematika siswa sebesar 42,5\%. Pengaruh penilaian kinerja siswa dapat meningkatkan hasil belajar hingga $25 \%$.

b. Berdasarkan analisa data kecerdasan emosional siswa dapat disimpulkan bahwa terdapat pengaruh yang positif dan signifikan antara kecerdasan emosional siswa terhadap hasil belajar matematika siswa sebesar 33,6\%. Pengaruh kecerdasan emosional siswa dapat meningkatkan hasil belajar hingga $21,6 \%$.

c. Berdasarkan analisa data penilaian kinerja dan kecerdasan emosional siswa dapat disimpulkan bahwa terdapat pengaruh yang positif dan signifikan antara penilaian kinerja siswa dan kecerdasan emosional siswa terhadap hasil belajar matematika siswa sebesar $60,7 \%$. Pengaruh kecerdasan emosional siswa dapat meningkatkan hasil belajar hingga $27,8 \%$.

\section{DAFTAR PUSTAKA}

Abdullah. (2017). Pendekatan dan Model Pembelajaran yang Mengaktifkan Siswa. Edureligia, $1(1), 45-62$.

Ermawati, S., \& Hidayat, T. (2017). Penilaian Autentik dan Relevansinya dengan Kualitas Hasil Pembelajaran. Jurnal Pendidikan Ilmu Sosial, 27(1), 92-103.

Goleman, Daniel. (2016). Emotional Intellegence Kecerdasan Emosional. (Hermaya T, Trans.) Jakarta: PT Gramedia Pustaka Utama.

Mahira. (2017). Evaluasi Belajar Peserta Didik (Siswa). Jurnal Pendidikan, 2(1), 22-28.

Meutia, H., Johar, R., \& Ahmad, A. (2013). Kemampuan Mahasiswa Calon Guru Menerapkan Penilaian Kinerja untuk Menilai Hasil Belajar Siswa dalam Pembelajaran Matematika. Jurnal Peluang, 1(2), 63-70.

Prasetyawati, P. (2016). Analisis Proses Pembelajaran Berbasis Student Centered Learning Dalam Pendekatan Saintifik Pada Mata Pelajaran Sejarah di SMA Negeri se Kota Palu. Katalogis, 4(10), 130-137.

Rohman, A. A., \& Karimah, S. (2018). Faktor-Faktor yang Mempengaruhi Rendahnya Motivasi Belajar Siswa Kelas XI. Jurnal At-Taqaddum, 10(1), 95-108. 
102 | Nanly O. P. H. Biantoro, Febriana Kristanti, Himmatul Mursyidah - Pengaruh Penilaian Kinerja dan Kecerdasan Emosional ....

Siti, F., \& Suharno, A. (2010). Meningkatkan Kecerdasan Emosional Melalui Bimbingan Konseling Kelompok. Jurnal Majalah Lontar, 24, 1-17.

Solehkhah, I., Slameto, \& Radia, E. H. (2018). Penerapan Model Pembelajaran Project Based Learning untuk Meningkatkan Hasil Belajar Matematika Kelas II SD. Jurnal Didakrika Dwija Indria, 6(2), 1-7.

Unengan, I. R., Ainy, C., \& Mursyidah, H. (2020). Implementasi Model Kooperatif TGT dengan Media Ludo Math untuk Meningkatkan Hasil dan Motivasi Belajar Siswa. JARTIKA: Jurnal Riset Teknologi dan Inovasi Pendidikan, 3(1), 113-126.

Wulan, A. R. (2008). Penilaian Kinerja dan Portofolio pada Pembelajaran Biologi. Jurnal Pendidikan, 2(1), 1-6. 